\title{
Intergenerational transfers and rosters of the extended family: a new substudy of the Panel Study of Income Dynamics
}

Robert F. Schoeni

bschoeni@umich.edu

Suzanne M. Bianchi

V. Joseph Hotz

Judith A. Seltzer

Emily E. Wiemers
University of Michigan, Michigan, US

University of California, Los Angeles, US

Duke University, Durham, US

University of California, Los Angeles, US

University of Massachusetts, Boston, US

(Received November $2014 \quad$ Revised February 2015)

http://dx.doi.org/10.14301/llcs.v6i3.332

\section{Abstract}

Family members provide support to each other at critical life stages. To better understand the pervasiveness, causes, and consequences of such support, a sub-study of the United States (U.S.) Panel Study of Income Dynamics (PSID) was created. A battery of questions on family relationships and intergenerational transfers was designed, pretested on a U.S. national telephone sample, and then administered in the 2013 wave of the PSID. These new data are available to the public. Given the extensive supporting data available on the respondents and members of their co-resident and non-co-resident family members - many of whom are interviewed themselves - the new sub-study will become a valuable resource to researchers.

Keywords: Intergenerational transfers; longitudinal research; family support; family structure

\section{Scientific motivation}

The extended family provides financial resources, time, housing assistance in the form of co-residence, and emotional support to its members to benefit individuals' wellbeing throughout life (Bianchi, Hotz, McGarry \& Seltzer, 2008). Parents are a primary source of financial support for their children's postsecondary education (Lovenheim, 2011) and also may provide support to help their children launch careers and purchase homes (Engelhardt \& Mayer, 1998; Cox \& Stark, 2005). Adult offspring may help elderly parents manage their lives at older ages and provide care at the end of life (Wolf, Soldo \& Freedman, 1996;
Wolf 1999). Family members may resume living with one another when a family member has a health problem, loses a job, or copes with marital problems or divorce (Kaplan, 2012; Ward, Logan \& Spitze, 1992). How family members help each other weather the vagaries of life can have lasting consequences for individuals' health and general wellbeing.

Intergenerational transfers may be especially important at the transition to adulthood and in later life when aging parents become infirm. As children become adults, parents help launch them, in part by giving them money or paying their expenses and by providing housing. Schoeni and Ross (2005) estimate 
that in the late 1980s an adult child age 18-34 received a total of $\$ 50,432$ (in 2013 dollars) in combined financial transfers and benefits from coresidence with parents. Transfers varied by parental income, from $\$ 30,799$ for young adults with parents in the bottom quartile of the income distribution to $\$ 93,347$ for those with parents in the top quartile. At the other end of life, about $40 \%$ of the disabled elderly rely on unpaid help (Spillman \& Pezzin, 2000). Adult children are the most common source of informal care, particularly for the unmarried elderly; $44 \%$ of primary caregivers are adult children (Center on an Aging Society, 2005). Time help also is an important way that children can help aging parents maintain independence (Kahn, McGill, \& Bianchi, 2011). Understanding the decisions families make about the care of the elderly and the family's role in providing care is increasingly important as the population ages and as the costs associated with nonfamily care rise.

Parents may treat each of their offspring differently in young adulthood and even earlier in life, transferring more to some than to other children in their family. The received wisdom is that parents make greater inter vivos transfers to their children in greater need (Altonji Hayashi, \& Kotlikoff 1997, 2000; McGarry \& Schoeni 1995, McGarry, 1997). However, findings by Zissimopoulos and Smith (2009) suggest that this conclusion is premature. Using Health and Retirement Study (HRS) longitudinal data, they find that parents' financial transfers among children in the same family may be more equal than researchers previously thought: when tracked over a 16 year period, $43 \%$ of parents who have given money to at least one child also gave money to all of their children, compared to only $11 \%$ in a two year period. In addition, amounts tended to become more equal across children over a longer time horizon. Some of the equalization in giving across children over time is due to large transfers, probably for college and buying a home, which occur at different times for different children. Collecting data on both short-term and long-term transfers over the life course is a significant contribution of the new PSID sub-study.

Several demographic and economic trends are likely to have important and far-reaching consequences for the provision and receipt of familial transfers. Family instability, due to divorce and repartnering, affects family members' capacity to transfer time, money, and co-residence across generations, the need for these transfers, and the willingness to participate in family exchanges. High rates of union dissolution and repartnering make stepfamilies and families formed by cohabitation more common now than in the past (Bumpass \& Lu, 2000; Kennedy \& Bumpass, 2008). Divorce may reduce parents' ability to help children and increase parents' need for help in old age (Furstenberg, Hoffman, \& Shrestha, 1995). Remarriage may further weaken the family safety net. Step-children are less likely than biological children to live with or provide help to older parents (Pezzin, Pollak, \& Steinberg Schone, 2008; Seltzer, Yahirun, \& Bianchi, 2013). Americans feel less obligation to care for step- than biological parents (Coleman \& Ganong, 2008) and parents who have both step and biological children receive less help overall than do parents who have only biological children (Eggebeen, 1992; Pezzin \& Steinberg Schone, 1999).

The recent Great Recession and the economy's slow rebound in many parts of the United States may impair the ability of many parents to finance not only their on-going needs, but also their ability to help finance their adult children's education and home ownership. Using PSID data, Lovenheim (2011) found that the rise in housing values during the first part of the 2000-10 decade significantly increased college enrollments, with the largest effects among less wealthy households. These results suggest that the more recent housing bust associated with the recession may reduce college attendance. Parents, particularly those in the hardest hit localities, who might have helped finance their children's college education by drawing on the equity in their homes, now find themselves with far fewer resources than they believed they had just a few years ago.

Disruptions in parents' lives are likely to affect their children's lives as well. As is well documented with PSID data, economic success is correlated across generations (Solon, 1992; Lee \& Solon, 2009; Charles \& Hurst, 2003). Estimates of the intergenerational correlation of economic attainment range from 0.3 to 0.7 depending on dataset, sample, and measures (Harding, Jencks, Lopoo, \& Mayer, 2005). But understanding the mechanisms that produce these correlations is less developed. Theories of 
intergenerational transfers (Becker and Tomes, 1979) imply that parents invest directly in the human capital of their children and use inter vivos transfers of wealth to enhance their offspring's wealth and capacity to produce it. Evidence of nonlinearities in the intergenerational elasticity of earnings suggests that variation in parents' circumstances affects the magnitude and mechanisms that contribute to the intergenerational transmission of economic wellbeing (Bratsberg et al., 2007). However, isolating the influence of these forms of parental transfers is complicated by the lack of information about the incidence and amounts of different types of transfers and the lack of information about exogenous factors which affect parent's ability to provide them.

To summarise, U.S. families are at a unique historical juncture, with the huge Baby Boom cohort facing retirement in uncertain economic times. This is a cohort for whom the family context was radically different than for their parents' generation. They experienced more family disruption, reduced fertility and smaller families but more step-kin, and the increased labour force participation of women. They raised their children during a period of rapidly rising income inequality in the U.S. (Autor, Katz, \& Kearney, 2008). This trend, coupled with the growing socioeconomic divide in family stability (McLanahan, 2004), may magnify family effects on the wellbeing of the next generation. The high level of persistence in economic circumstances across generations may make it difficult for those at the bottom to live healthy and secure lives in retirement, and they are unlikely to have children who are able to provide them with additional resources.

\section{Questions that can be addressed}

Data from the new PSID sub-study will allow researchers to investigate how parents and offspring use the scarce resources of time and money to alleviate economic distress. The list of scientific questions that can be addressed is long, particularly when these new data are combined with the rich array of social, economic, and health data on individuals and their family members that have been collected during the prior 45 years of the PSID. Because respondents and their family members have been interviewed in the past and will continue to be interviewed into the future, the new sub-study data provide new opportunities to investigate how past circumstances influenced large transfers for schooling and housing and how family characteristics and behaviour reported in the 2013 sub-study influence subsequent social and economic outcomes.

These new data allow researchers to describe the intergenerational structure of American families both within and across households and the transfers that family members make to one another across adult ages - something that, to our knowledge, is not possible with any other nationally representative dataset. These data also allow researchers to investigate how health and economic circumstances of parents and children are correlated with transfers and whether these patterns differ by life stage, demographic characteristics such as education, race, and marital status, and intergenerational family structure. The inclusion of questions on transfers for schooling and housing in an intergenerational study allows for a deeper understanding of how these transfers shape the intergenerational transmission of economic advantage. Furthermore, researchers can compare family transfers in 2013 with data on transfers collected in the 1988 PSID to see if intergenerational support has changed along with changes in family structure and economic circumstances.

\section{PSID as a vehicle for studying families}

\section{and intergenerational transfers}

The PSID is the premier dataset in the United States for studying how life course and intergenerational processes contribute to individual well-being because of its prospective, repeated measures of individuals' economic characteristics, health, living arrangements, its genealogical design, its long life histories of linked family members, and its high wave-to-wave response rates. Launched in 1968, the study follows individuals whether or not they are living in the same dwelling as the original sample household or with the same people. Children who grow up and leave their parents' household become what PSID calls "split-offs," and these children continue to be followed and interviewed as they establish their own households, have children themselves, and even when they sometimes move back in with their parents. Interviews were conducted 
annually until 1997 when PSID moved to an every other year schedule.

All individuals in households recruited into the PSID in 1968 are said to have the PSID 'gene'. All individuals who are born to or adopted by someone with the PSID gene acquire the gene themselves and therefore are followed and become members of the PSID sample for the rest of their lives. This design feature implies that the study provides, at each wave, data on a sample of extended families, or dynasties. Because it is longitudinal, the PSID provides, across its waves, data on the households and members of multi-generational dynasties at various points in their lives. To facilitate genealogic analyses in which parents and children, siblings, and three-generation families are linked, PSID provides the Family Identification Mapping System (FIMS) tool to allow users to easily create inter- and intra-generational samples.

Americans of all ages are captured by the PSID sampling strategy and then followed throughout their lives. This design allows investigation of intergenerational transfers across the entire life course, including assistance given/received during the years when critical decisions are made about human capital investments, family formation, and homeownership. This feature is particularly important for disadvantaged populations because they leave home earlier, have grandchildren earlier, and experience significant health challenges earlier than more advantaged populations. Surveys that focus just on older populations do not measure these important events.

Despite the undisputed merit of its genealogical design, the fact that non-gened family members, whose needs and resources affect the welfare of gened respondents, are not included in the sample is a disadvantage. For example, if today a 25 -year-old woman who is a gened sample member gets married (and her husband does not have the PSID gene), the PSID contains information on the health and economic status of her parents, because they, themselves, are sample members, but not detailed information on the health and economic status of her spouse's parents. Information on both sets of parents' needs and resources is required to understand why an adult child's family may give help to parents but not parents-in-law. The 2013 Family
Roster and Family Transfer sub-study addresses this shortcoming of the PSID for studying intergenerational transfers (Bianchi et al., 2008).

When it began in 1968 the PSID had a sample of 18,230 individuals living in 4,802 households. The sample size has changed over time for a number of reasons including mortality, attrition, births, addition of a sample of new immigrants, and dropping of a portion of the sample due to budget cuts. In 2013, interviews were conducted with 9,107 households containing nearly 25,000 individuals. Since 1969 , the wave-to-wave response rate has been $91 \%-98 \%$. The evolution of the sample size is described in detail in the PSID User Manual.

A number of studies have examined the representativeness of the PSID and selective attrition. The findings from these studies were recently summarised in this journal (McGonagle, Schoeni, Sastry, \& Freedman, 2012). Studies find that the PSID estimates of a variety of socioeconomic characteristics of individuals are similar to estimates from contemporary cross-sectional gold standard surveys. The correspondence between the PSID and cross-sectional surveys is close even though attrition has been found to be associated with characteristics of respondents; notably there is higher attrition among lower income individuals. Nevertheless the PSID comparisons with other national survey data sources suggest that the Roster and Transfer substudy will provide estimates that are representative of American families. An indication of its value as a survey representative of the U.S. population is the PSID's inclusion in the Cross-National Equivalent File, a major data source for comparative research (http://cnef.ehe.osu.edu/).

\section{Instrument design, testing, and}

\section{implementation}

The battery of questions in the sub-study included a roster of parents and children age 18 and older. The questions identified biological and step relationships, and asked about transfers to and from these family members regardless of where they lived.

\section{Family roster}

We designed a new roster of family members to list parents and parents-in-law, children, step-parents, and step-children of PSID Heads and Wives ${ }^{1}$. As 
discussed above, the PSID's family-based following rules imply that the PSID already has substantial information about respondents' relatives because they have the PSID gene and are respondents themselves. However, data are not available for relatives of PSID households that do not have the PSID gene or for gened relatives who missed various waves and/or attrited from the study. For example, among married couples in which one spouse does not have the PSID gene, the non-gened spouse's parents and children from prior unions (stepchildren to the PSID-gened respondent) are not interviewed. Therefore, the roster obtained information about all current living adult children, stepchildren, parents, and step-parents of Heads and Wives in the main interview in 2013. Adult children were defined as those age 18 and older. For each adult (step)child and (step)parent, we collected: name, relationship to head/wife, gender, date of birth or age, marital status (including cohabitation for adult children), city and state of residence, educational attainment (for adult children; education of parents already exists in the PSID database), subjective general health status (excellent, very good, good, fair, poor), homeownership, and employment status. For adult offspring we also asked how many children they had. The total numbers of living siblings for the Head and the Wife also were collected because siblings are an important determinant of whether the responding adult child provides support to parents.

The roster includes the names of the full set of adult children and parents. When respondents stated that they had given (received) a transfer, they were asked to (by) whom the transfer was given (received). Interviewers had the family roster displayed on their computers, allowing them to easily select the correct individual; therefore, not only do we know that the respondent gave transfers to a child, we know which child, and the transfer can be linked to the information about that child that is reported in the roster as well as information on the child's PSID family for those children who are living in interviewed PSID family units.

\section{Family transfers}

The 2013 transfers module had two parts, with reference to each PSID Head and Wife: part one asked about recent transfers of time and money (over \$100) given to and received from parents and parents in-law and about transfers of time and money given to and received from children and step-children in the last year; part two asked about large, life-cycle transfers of money that the Head/Wife received from parents since age 18 and about large transfers of money given to children and stepchildren since they were 18 years old. Table 1 outlines the questions.

\section{Recent transfers}

Questions were asked about the incidence and amount of transfers of money and time given and received over the last year. Respondents were asked about transfers with parents and children and were allowed to report transfers with both co-resident and non-co-resident parents and children. Similar questions have appeared in the PSID in the past. Table 2 outlines the transfer questions that were asked in a transfer module administered in the 1988 wave of the PSID and indicates when co-resident kin were included. As table 2 shows, respondents were asked about transfers with parents and were asked a general question about transfers with others. In both 1988 and 2013, respondents were asked enough information about the person with whom they engaged in transfers to link these transfers to specific individuals (including children). While maintaining as much comparability as possible with the 1988 PSID, we improved the questions in 2013 by designing specific questions about money and time transfers to children and stepchildren rather than relying on the more general question about transfers with others utilized in 1988 and by uniformly including coresident family members. (See ftp://ftp.isr.umich.edu/pub/src/psid/questionnaires/ q88.pdf for the 1988 questions.) If time transfers were reported in 2013, we also asked which person, the Head or Wife, gave most of the time transfers. While money transfers can be thought of as a transfer from one household to another, time transfers can be assessed for individuals within households.

\section{Long-term, life-cycle transfers}

The sub-study includes questions about large transfers that the Head and Wife of a PSID household each may have received from their parents (whether or not the parents are alive in 2013) and/or provided to their children since they/their children were age 18. The bottom panel of table 1 outlines the long- 
term transfer questions that were asked and when amounts were included. Two specific large life-cycle transfers were assessed-one for post-secondary education and a second for help with the purchase of a home-along with a more general question on large financial transfers between parents and their adult children. These questions capture retrospective information about important and salient types of transfers. For transfers to offspring, both whether assistance was provided and the amount of assistance was assessed. However, for transfers from parents only yes/no was assessed because of the potentially long recall period. Until 2013, the PSID had never asked these types of life-cycle transfer questions.

The roster and transfer module, as well as the entire PSID instrument administered in 2013, are available on the PSID website: ftp://ftp.isr.umich.edu/pub/src/psid/questionnaires/ q2013.pdf.

\section{Content that could not be included}

The sub-study was constrained to including interview questions that totaled no more than 12 minutes on average across all respondents. This constraint was required by the Directors of the PSID to avoid overburdening respondents, with an average interview length of 94 minutes in total including other topics captured by the survey. Therefore, the project team was forced to make some difficult choices. Two sets of questions were the most difficult to exclude. First, the project team was hoping to include a roster of respondent's siblings, including half and stepsiblings, and their characteristics, as well as questions about transfers to and from siblings. Second, the team would have liked to have included additional measures such as relationship quality, recent episodes of unemployment, health events, intensity of time help, for instance hours of time help in each week, and changes in family structure such as divorce or marriage. We chose to exclude the roster of siblings because transfers of money and time help with siblings are much less common than transfers with parents or adult children (Kahn et al., 2011; Schoeni, 1997). Our choice of characteristics to measure for individuals included in the roster was based on findings from prior literature on the most salient determinants of money and time transfers as well as evidence on which characteristics could be accurately reported by a parent or adult child with only a small number of questions. Another decision the investigators made based on timing estimates from the PSID pretest was to shorten question stems by deleting explanations of types of financial and time transfers to include in responses. The shorter question stems had the advantage of making the module shorter and more conversational. But by excluding examples, the questions may have elicited responses with more underlying variation in the definitions that respondents used to inform their answers (Schaeffer \& Presser, 2003). Finally, the investigators chose to exclude amounts from questions about long-term transfers received from parents or spouse's parents because of time constraints on the length of the interview and pretesting for the pilot study suggested that respondents had difficulty reporting amounts of longterm money received, particularly by their spouse. This finding is not surprising given that many respondents had not married their spouse until well after such transfers were received.

\section{Pilot test on national sample}

The roster and transfer module was tested on the June 2012 Michigan Survey of Consumer Attitudes (SCA). SCA is a telephone survey of a national probability sample of U.S. adults age 18 and older. The survey collected data from 495 respondents. Approximately two thirds of respondents, 314, had adult children, and these parent respondents provided information on 789 adult children. These data are expected to become available at the University of Michigan's Inter-University Consortium for Political and Social Research by August 2015.

\section{Survey field effort}

The roster and transfer questions were included in the 2013 PSID main interview. The Survey Research Operations group at the Institute for Social Research, University of Michigan, fielded the survey. The 115 interviewers were located throughout the United States, and they were required to successfully complete in-person training prior to beginning fieldwork. At training, interviewers were instructed on PSID specific terminology and procedures, and they were required to pass an examination on this material before beginning fieldwork. Interviewing began in March and finished at the end of December. 
Interviews were obtained with 9,107 family units. The re-interview response rate was $95 \%$. Of the completed interviews, $97 \%$ were conducted on the telephone and the remainder face-to-face. A cell phone was used by $80 \%$ of telephone respondents. The average number of calls to complete an interview was 14.1 , with a median of six. Nearly a quarter, $23 \%$, of completed cases required multiple sessions to finish the interview.

Various strategies were used to maximize response rates. Respondents were provided with a $\$ 70$ incentive, which was mailed to them after completing the interview. To compensate for the use of paid minutes of phone time, respondents using a cell phone were offered an additional \$10. Interviewers who worked for PSID previously were assigned to cases they had successfully interviewed in the past. Approximately six months before fieldwork began, sample members were mailed a newsletter that provided short articles describing new research findings based on the PSID. A postcard was also sent to respondents seeking updated contact information. Respondents were sent a $\$ 10$ check if they returned the postcard with updated information.

\section{Data access, ethical approval, and funding source}

PSID data and documentation for all survey years are freely available on the PSID website: www.PSID.org. Users can download all data for a particular year as one large file. Alternatively, the PSID website will create customised cross-year extracts, with users simply choosing the variables they require from each year. Among the thousands of variables are characteristics of the interview process including interview length, number of calls to complete the interview, mode of interview (telephone versus face-to-face), interviewer identification number, date of interview, and a lengthy set of interviewer observations about the interview process for each particular respondent.

An initial release of the 2013 transfer and roster data and documentation, along with a video introduction to the sub-study, is available online at http://simba.isr.umich.edu/Zips/zipSupp.aspx\#RAT13. The final and fully edited version of the data is scheduled to be released fall of 2015 .

The University of Michigan Health Sciences and
Behavioral Sciences Institutional Review Board reviewed and approved the 2013 PSID data collection and distribution protocols and survey instrument to ensure the rights and welfare of research participants were protected.

Funding for this sub-study was provided by the U.S. National Institute on Aging through a program project grant (P01AG029409).

\section{Item non-response}

Tables 3 and 4 report un-weighted frequencies of money and time transfers between dyads of parent units and children. We refer to 'parent units' because questions about transfers to and from married (or cohabiting) parents did not distinguish between transfers to (from) individual parents. The tables include the percentage of responses where the respondent reported they did not know the answer to the question or refused to answer. The rates of nonresponse are quite low, no higher than $4 \%$. For example, table 3 shows that among all child respondent-parent pairs, time help in the past year was given to parents in $32 \%$ of cases, time help was not given in $66 \%$ of cases and only $2 \%$ of respondentparent pairs were item nonresponse.

The top panel of table 4 reports the percentage of parent-unit-child pairs in which the parent reported that they gave the child money for schooling, to buy a home, or something else since the child was age 18. The bottom panels show the percentage of Heads and Wives who reported receiving such help from parents since age 18. As for reports about short-term transfers, there are low percentages of item nonresponse. This is especially notable because the respondent reports about his or her own parents as well as the spouse's parents, and knowledge about long-term transfers to a spouse might be more limited than knowledge about transfers from the respondent's own parents.

\section{Conclusions}

There have been fundamental changes in the family, the economy, and the social safety net in the United States over the last few decades. The new Roster and Transfers sub-study of the PSID will allow researchers to document many of these changes, as well as examine the impact of these changes on families and individuals. 
The sub-study highlights the importance of ongoing longitudinal studies. By including the substudy in the PSID, researchers can draw upon the 45 years of information on respondents and their families to more fully understand the causes and consequences of intergenerational transfers. Moreover, as more and different data are collected in future waves of the PSID, the data collected in the 2013 sub-study can be utilized in conjunction with future data to assess the impact of intergenerational transfers.

The addition of this sub-study to the long-running PSID may motivate the addition of similar modules to the ongoing panel studies in the other countries represented in the Cross-National Equivalence File, including the British Household Panel Study (BHPS), the Australian Household Income and Labor Dynamics Study (HILDA), the Korean Labor and Income Panel
Study (KLIPS), the Russia Longitudinal Monitoring Survey (RLMS), the Canadian Survey of Labour and Income Dynamics (SLID), and the German SocioEconomic Panel (SOEP). Inclusion in even a small number of these studies would enable comparative research on how private transfers among family members complement or substitute for public transfers or government support. The different institutional contexts represented by these surveys, particularly variation in arrangements for postsecondary schooling, child care, and old age support, would shed important light on explanations for intra-family transfers of time and money. Even without the potential for new data to support this comparative effort, the roster and transfer sub-study in the PSID is a valuable new public resource for investigating the familial process that may contribute to inequality within and between generations.

\section{Acknowledgements}

Funding for this sub-study was provided by the United States National Institute on Aging (P01AG029409). This work was also supported, in part, by the Duke Population Research Institute (DuPRI), which receives core support from grant P30-AG034424 funded by the National Institute on Aging, and the California Center for Population Research at UCLA (CCPR), which receives core support (R24- HD041022) from the Eunice Kennedy Shriver National Institute of Child Health and Human Development (NICHD).

\section{References}

Altonji, J.G., Hayashi, F., \& Kotlikoff, L.J. (1997). Parental Altruism and Inter Vivos Transfers: Theory and Evidence. Journal of Political Economy, 105(6), 1121-66. http://dx.doi.org/10.1086/516388

Autor, D.H., Katz, L.F., \& Kearney, M.S. (2008). Trends in U.S. Wage Inequality: Revising the Revisionists. Review of Economics and Statistics, 90(2), 300-323 http://dx.doi.org/10.1162/rest.90.2.300

Becker, G.S. and Tomes, N. (1979). "An Equilibrium Theory of the Distribution of Income and Intergenerational Mobility." Journal of Political Economy, 87(6): 1153-1189. http://dx.doi.org/10.1086/260831

Bianchi, S.M., Hotz, V.J., McGarry, K., \&, Seltzer, J.A. (2008). Intergenerational Ties: Theories, Trends, and Challenges. In A. Booth, A.C. Crouter, S.M. Bianchi, \& J.A. Seltzer (Eds.), Intergenerational Caregiving (pp. 343). Washington DC: Urban Institute Press.

Bratsberg, B., Røed, K., Raaum, O., Naylor, R., Jäntti, M., Eriksson, T., Österbacka, E., \& Björklund, A. (2007). Nonlinearities in Intergenerational Earnings Mobility: Consequences for Cross-Country Comparisons. Economic Journal, 117(519), C72-C92. http://dx.doi.org/10.1111/j.1468-0297.2007.02036.x

Bumpass, L., \& Lu, H.H. (2000). Trends in Cohabitation and Implications for Children's Family Contexts in the U.S. Population Studies, 54, 29-41

Center on an Aging Society. (2005). Adult Children: The Likelihood of Providing Care for an Older Parent. Data Profile Number 2. Washington, DC: Georgetown University. 
Charles, K.K. \& Hurst, E. (2003). The Correlation of Wealth across Generations. Journal of Political Economy, 111(6), 1155-1182.

http://dx.doi.org/10.1086/378526

Coleman, M., \& Ganong, L. (2008). Normative Beliefs About Sharing Housing with an Older Family Member. International Journal of Aging and Human Development, 66, 49-72.

http://dx.doi.org/10.2190/AG.66.1.c

Cox, D., \& Stark,O. (2005). On the Demand for Grandchildren: Tied Transfers, Liquidity Constraints and the 'Demonstration Effect'. Journal of Public Economics, 89, 665-697. http://dx.doi.org/10.1016/j.jpubeco.2004.04.005

Eggebeen, D.J. (1992). Family Structure and Intergenerational Exchanges. Research on Aging,14, 427-447. http://dx.doi.org/10.1177/0164027592144001

Engelhardt, G.V., \& Mayer, C.J. (1998). Intergenerational Transfers, Borrowing Constraints, and Saving Behavior: Evidence from the Housing Market. Journal of Urban Economics, 44(1), 135-157. http://dx.doi.org/10.1006/juec.1997.2064

Furstenberg, F.F.,Jr., Hoffman, S.D., \& Shrestha, L. (1995). The Effect of Divorce on Intergenerational Transfers: New Evidence. Demography, 32(3), 319-333. http://dx.doi.org/10.2307/2061683

Harding, D.J., Jencks, C., Lopoo, L.M., \& Mayer, S.E. (2005). The Changing Effect of Family Background on the Incomes of American Adults. In S. Bowles, H. Gintis, \& M. Osborne Groves (Eds.), Unequal Chances: Family Background and Economic Success (pp. 100-144). Princeton, NJ: Russell Sage Foundation and Princeton University Press.

Kahn, J.R., McGill, B.S., \& Bianchi, S.M. (2011). Help to Family and Friends: Are There Gender Differences at Older Ages? Journal of Marriage and Family. NIHMS: NIHMS269750

Kaplan, Greg. 2012. "Moving Back Home: Insurance Against Labor Market Risk." Journal of Political Economy, 120(3): 446-512. http://dx.doi.org/10.1086/666588

Kennedy, S., \& Bumpass, L. (2008). Cohabitation and Children's Living Arrangements: New Estimates from the United States. Demographic Research, 19, 1663-1692. PMCID: PMC2612998 http://dx.doi.org/10.4054/DemRes.2008.19.47

Lee, C.I., \& Solon, G. (2009). Trends in Intergenerational Income Mobility. Review of Economics and Statistics, 91(4), 766-772.

http://dx.doi.org/10.1162/rest.91.4.766

Lovenheim, M.F. (2011). The Effect of Liquid Housing Wealth on College Enrollment. Journal of Labor Economics, 29(4) (October 2011), pp. 741-771. http://dx.doi.org/10.1086/660775

McGarry, K., \& Schoeni, R. (1995). Transfer Behavior in the Health and Retirement Study. Journal of Human Resources, 30 (supplement): S184-S226.

http://dx.doi.org/10.2307/146283

McGarry, K. (1997). Transfer Behavior within the Family: Results from the Asset and Health Dynamics Study. Journals of Gerontology, 52B: 82-92. http://dx.doi.org/10.1093/geronb/52B.Special_Issue.82

McLanahan, S. (2004). Diverging Destinies: How Children Are Faring Under the Second Demographic Transition. Demography, 41(4), 607-627. http://dx.doi.org/10.1353/dem.2004.0033

K. McGonagle, R. Schoeni, N. Sastry, V. Freedman. (2012) The Panel Study of Income Dynamics: Overview, recent renovations, and potential for life course research. Longitudinal and Life Course Studies, 3, 268-284.

Pezzin, L.E., \& Steinberg Schone, B. (1999). Parental Marital Disruption and Intergenerational Transfers: An Analysis of Lone Elderly Parents and Their Children. Demography, 36, 287-297. http://dx.doi.org/10.2307/2648053

Pezzin, L.E., Pollak, R.A., \& Steinberg Schone, B. (2008). Parental Marital Disruption, Family Type, and Transfers to Disabled Elderly Parents. Journal of Gerontology: Social Sciences, 63B(6), S349-S358.

http://dx.doi.org/10.1093/geronb/63.6.S349 
Schaeffer, N. C., Presser, S. (2003). The Science of Asking Questions. Annual Review of Sociology, 29, 65-88. http://dx.doi.org/10.1146/annurev.soc.29.110702.110112

Schoeni, R. (1997). Private Interhousehold Transfers of Money and Time: New Empirical Evidence, Review of Income and Wealth 43(4), 423-448.

http://dx.doi.org/10.1111/j.1475-4991.1997.tb00234.x

Schoeni, R.F., \& Ross, K.E. (2005). Material Assistance from Families during the Transition to Adulthood. In R. A. Settersten, Jr., F.F. Furstenberg, Jr., \& R.G. Rumbaut (Eds.), On the Frontier of Adulthood, (pp. 396-416). Chicago: University of Chicago Press. http://dx.doi.org/10.7208/chicago/9780226748924.003.0012

Seltzer, J. A., Yahirun, J.J., \& Bianchi, S.B. 2013. Coresidence and Geographic Proximity of Mothers and Adult Children in Stepfamilies. Journal of Marriage and Family 75(5), 1164-80. http://dx.doi.org/10.1111/jomf.12058

Solon, G.R. (1992). Intergenerational Income Mobility in the United States. American Economic Review, 82(3), 393-408.

Spillman, B.C., \& Pezzin, L.E. (2000). Potential and Active Family Caregivers: Changing Networks and the 'Sandwich Generation'. Milbank Quarterly, 78(3), 347-374. http://dx.doi.org/10.1111/1468-0009.00177

Ward, R., Logan, J., \& Spitze, G. (1992). The Influence of Parent and Child Needs on Coresidence in Middle and Later Life. Journal of Marriage and Family, 54(1), 209-221 http://dx.doi.org/10.2307/353288

Wolf, D.A., Soldo, B., \& Freedman, V. (1996). The Demography of Family Care for the Elderly. In T. Hareven (Ed.), Aging and Generational Relations Over the Life Course : A Historical and Cross-Cultural Perspective, (pp.115138). Hawthorne, NY: Walter de Gruyter, Los Angeles, CA: Rand Corporation. http://dx.doi.org/10.1177/089826439901100306

Wolf, D.A. (1999). The Family as Provider of Long-Term Care: Efficiency, Equity, and Externalities. Journal of Aging and Health, 11(3), 30-82.

Zissimopoulos, J., \& Smith, J.P. (2009). Unequal Giving: Monetary Gifts to Children Across Countries and Over Time. Rand Labor and Population Working Paper No. WR-723, Los Angeles, CA: Rand Corporation.

\section{Endnotes}

${ }^{1}$ PSID defines household headship as the Census did when the PSID began. In a husband-wife household the husband is designated the Head, regardless of whether he has the PSID gene. 


\section{Table 1. Summary of 2013 transfer questions}

Type of Help/Transfer

Amount

Collected?

Panel A. Recent Transfers

Transfers in last year to/from parents/children of PSID Heads and Wives

Time Given

Time Received

Money Given $(\$ 100+)$

Money Received $(\$ 100+)$

Y

Y

Y

Y

Living Arrangements with PSID HH:

Co-Residence

$N / A$

\section{Panel B. Long Term, Life-cycle Transfers}

Transfers since age 18 to/from parents/children of PSID Heads and Wives

Help with post-secondary education given to children

Help with post-secondary education received from parents

N

Help with home purchase given to children

Y

Help with home purchase received from parents

$\mathrm{N}$

Other large transfers given to children

$\mathrm{Y}$

Other large transfers received from parents

$\mathrm{N}$

Table 2. Summary of 1988 transfer questions

\begin{tabular}{|c|c|c|c|}
\hline \multirow[t]{2}{*}{ Type of Help/Transfer } & \multirow[t]{2}{*}{$\begin{array}{l}\text { Separate questions } \\
\text { for parents vs. non- } \\
\text { parents? }\end{array}$} & \multicolumn{2}{|c|}{$\begin{array}{l}\text { Did the other party reside in or outside } \\
\text { the PSID family at the time of the } 1988 \\
\text { Interview? }\end{array}$} \\
\hline & & $\begin{array}{l}\text { Transfer with } \\
\text { Parent }\end{array}$ & Transfer with Non-parent \\
\hline Time Given & $Y$ & In or Outside & Outside \\
\hline Time Received & Y & In or Outside & Outside \\
\hline Money Given $(\$ 100+)$ & $\mathrm{N}$ & Outside & Outside \\
\hline Money Received $(\$ 100+)$ & Y & In or Outside & Outside \\
\hline
\end{tabular}


Table 3. Types of transfers in the last year and item nonresponse (\%)

\begin{tabular}{lcccc}
\hline & $\begin{array}{l}\text { Money Given } \\
(\mathbf{\$ 1 0 0 + )}\end{array}$ & $\begin{array}{l}\text { Money Received } \\
\mathbf{( \$ 1 0 0 + )}\end{array}$ & Time Given & Time Received \\
\hline \hline Children (N=11511) & & & & \\
Yes & $29 \%$ & $8 \%$ & $28 \%$ & $21 \%$ \\
No & $69 \%$ & $91 \%$ & $68 \%$ & $76 \%$ \\
DK/RF & $2 \%$ & $1 \%$ & $4 \%$ & $2 \%$ \\
\hline Parent Units (N=12845) & $14 \%$ & & & \\
Yes & $85 \%$ & $17 \%$ & $32 \%$ & $26 \%$ \\
No & $1 \%$ & $82 \%$ & $66 \%$ & $73 \%$ \\
DK/RF & $1 \%$ & $2 \%$ & $1 \%$ \\
\hline
\end{tabular}

Table 4. Types of transfers since age 18 and item nonresponse (\%)

\begin{tabular}{lccc}
\hline & Money for School & Money for Home & Money for Other \\
\hline \hline Children (N=11511) & & & \\
Yes & $18 \%$ & $2 \%$ & $10 \%$ \\
No & $79 \%$ & $97 \%$ & $88 \%$ \\
DK/RF & $4 \%$ & $0 \%$ & $2 \%$ \\
\hline Head (N=9107) & & & \\
Yes & $20 \%$ & $5 \%$ & $17 \%$ \\
No & $79 \%$ & $94 \%$ & $82 \%$ \\
DK/RF & $1 \%$ & $0 \%$ & $1 \%$ \\
\hline Wife (N=4638) & & & \\
Yes & $24 \%$ & $6 \%$ & $13 \%$ \\
No & $76 \%$ & $94 \%$ & $87 \%$ \\
DK/RF & $1 \%$ & $0 \%$ & $0 \%$ \\
\hline
\end{tabular}

